\title{
SEASONAL CHANGES IN SELECTED INDICATORS OF WATER QUALITY OF THE ŁYDYNIA RIVER
}

\author{
Marek Gugała' ${ }^{1}$ Anna Sikorska' ${ }^{1}$ Krzysztof Kapela ${ }^{1}$, Krystyna Zarzecka ${ }^{1}$ \\ 1 Siedlce University of Natural Sciences and Humanities, Prusa 14, 08-110 Siedlce, Poland, e-mail: gugala@uph. \\ edu.pl; aniasikorska6@wp.pl
}

Received: 2015.11.20

Accepted: 2015.12.09

Published: 2016.01.06

\begin{abstract}
The objective of the research was to compare seasonal changes in selected indicators of water quality of the Łydynia river against Regulation of the Minister of Environment of 9 November 2011 on classification method for waterbody of surface waters and environmental quality standards for priority substances (Dz. U. [Journal of Laws] 2011, No. 257, item 1545). Water samples were taken in Ciechanów in the spring and autumn from 2009 to 2011. Water $\mathrm{pH}$, specific conductance and calcium ion $\left(\mathrm{Ca}^{2+}\right)$ and magnesium ion $\left(\mathrm{Mg}^{2+}\right)$ concentrations were determined as part of physical and chemical analysis. The study results were compared with the limit values of water quality indicators established in annex no. 1 for the aforementioned regulation. The water quality of the Łydynia river was found to be class I water (class I being the highest purity class). Additionally, colour and turbidity (the parameters not included in the aforementioned regulation) were determined in water samples.
\end{abstract}

Keywords: river, physical and chemical indicators, water quality, seasonality.

\section{INTRODUCTION}

Surface waters, which provide the habitat for many plant and animal organisms, are polluted due to human activity. An increasing anthropogenic impact results in permanent changes in water ecosystems [Bonisławska et al. 2008]. According to Natkaniec and Możdżeń [2013], pollution is not only due to excessive concentration of mineral or organic compounds but also unfavourable changes in water temperature, turbidity and colour. The author believes that rivers which receive industrial waste waters and surface and ground waters sent from arable land are the most threatened with pollution.

Ecological assessment of water quality is carried out using physical and chemical, biological as well as hydromorphological indicators [Directive 2000].

Data of the Chief Inspectorate of Environmental Protection indicate that in 2013 only 27 $(3 \%)$ of homogenous parts of surface waters (HPSW), which include rivers, met standards set for class I waters (class I being the highest purity class). A total of 252 rivers (27.6\%) were classified as good quality water bodies, 439 rivers $(48.1 \%)$ were in a moderate ecological condition, and the status of 46 rivers (5\%) was poor.

The objective of the research was to compare seasonal (spring, autumn) changes in physical and chemical parameters of water quality of the Łydynia river against Regulation of the Minister of Environment of 9 November 2011 on classification method for waterbody of surface waters and environmental quality standards for priority substances (Dz. U. 2011, No. 257, item 1545).

\section{STUDY AREA}

The Lydynia river is located in the north-eastern part of the Mazovian Lowland and runs across the Ciechanów Highland. It is $72 \mathrm{~km}$ long. Along the river, extends the natural and scenic area 'Łydyna River Valley’ which covers 57.31 ha.

The Łydynia river starts in Mława District in the proximity of Budy Garwolińskie, the ZielunRzęgnów Area of Protected Landscape, and 
flows into the Wkra river in Płońsk District, 1.5 $\mathrm{km}$ south of Gutarzewo, the Krosno-Kosmowo Area of Protected Landscape. The whole river area varies in width from 250 to $800 \mathrm{~m}$ and cuts into a moraine upland to the depth of less than 20 meters. The valley is covered with glacial and Holocene deposits (respectively, sands and turfs).

\section{MATERIALS AND METHODS}

Water was examined in Ciechanów during two study periods (spring, autumn) from 2009 to 2011. Physical and chemical analysis included determination of colour, $\mathrm{pH}$, turbidity, specific conductance, calcium ion $\left(\mathrm{Ca}^{2+}\right)$ concentration and magnesium ion $\left(\mathrm{Mg}^{2+}\right)$ concentration. Methods recommended by the Polish Standards were used and procedures described by Dojlido [1995] as well as Hermanowicz et al. [1996] were applied. Selected indicators of pollution were related to quality classes of surface waters based on the Regulation of the Minister of Environment of 9 November 2011 on classification method for waterbody of surface waters and environmental quality standards for priority substances (Dz. U. 2011, No. 257, item 1545).

\section{RESULTS AND DICUSSION}

According to Borowski [2010], colour of surface waters is usually determined by substances which are either diluted or suspended in water. The analyses demonstrated that water colour in spring ranged from 22 to $25 \mathrm{mg} \mathrm{Pt} \cdot \mathrm{dm}^{-3}$, the highest value being recorded in 2010 and the lowest in 2009. In the autumn, the indicator was higher and ranged from 27 to $32 \mathrm{mg} \mathrm{Pt} \cdot \mathrm{dm}^{-3}$ (Figure 1).

Water turbidity is determined by the occurrence of insoluble non-organic and organic particles which disperse or absorb light rays. Values of this parameter depend on river bed type and river water state. Figure 2 demonstrates changes in the turbidity of the Lydynia river throughout spring and autumn. Values of the indicator were found to be similar and ranged from 1.5 to $2.0 \mathrm{mg}$ $\mathrm{SiO}_{2} \cdot \mathrm{dm}^{-3}$. Moreover, $\mathrm{pH}$ in spring fell within the range of 7.4-8.3, the fluctuations occurring possibly due to the development of algae and depletion of carbon dioxide diluted in water resulting in calcium carbonate transformations. In autumn, $\mathrm{pH}$ ranged from 7.1 to 7.5 (Figure 3). The values of the indicator were found to relate to class I water [Regulation of the Minister of Environment of 9 November 2011]. In studies by other authors, $\mathrm{pH}$ of natural waters ranged from 6.5 to 8.5. Chomutowska and Wilamowski [2014] obtained $\mathrm{pH}$ values (the Łutownia river) ranging from 7.59 to 7.83. By contrast, Płytka et al. [2013] reported values for the Bochotniczanka river in the range from 7.29 to 8.29.

Specific conductance is a physical indicator which is indicative of mineral contamination of water. Augustyn et al. [2012] have stressed that its value is affected by quantitative contaminants occurring in a given area. According to Dojlido [1995], Olszewska and Krzemińska [2007], Ostrowski et al. [2007], specific conductance of surface waters ranges from 50 to $1000 \mu \mathrm{S} \cdot \mathrm{cm}^{-1}$.

The results obtained in the present work indicate that there were seasonal fluctuations in the values of this parameter. The highest specific

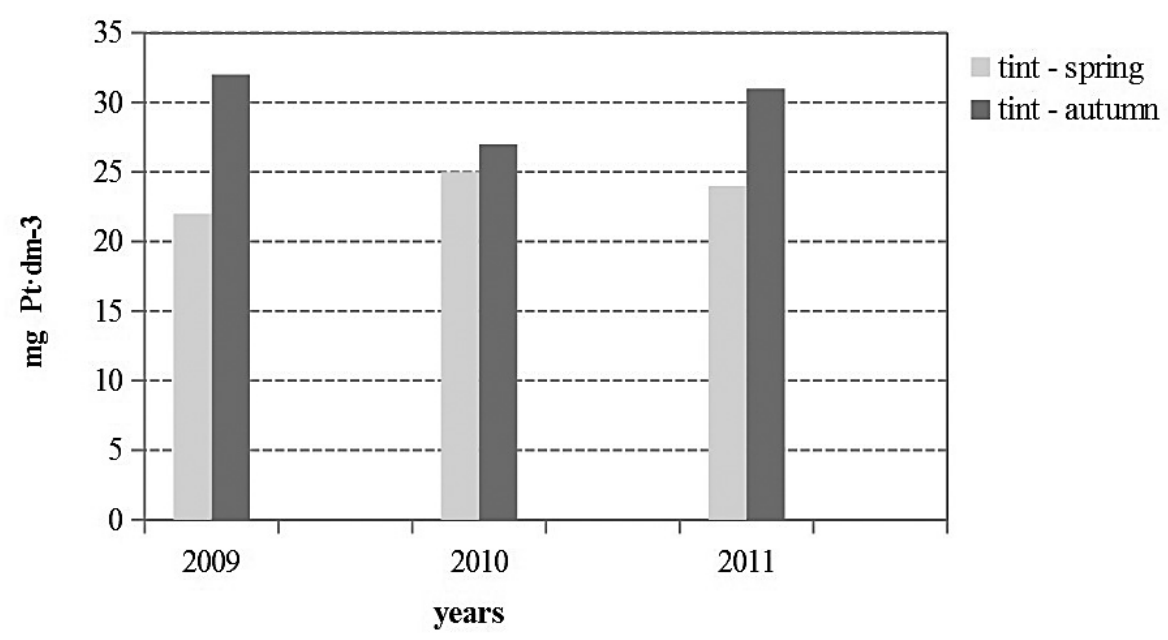

Figure 1. Seasonal changes in the tint in the Eydynia River in 2000-2011 


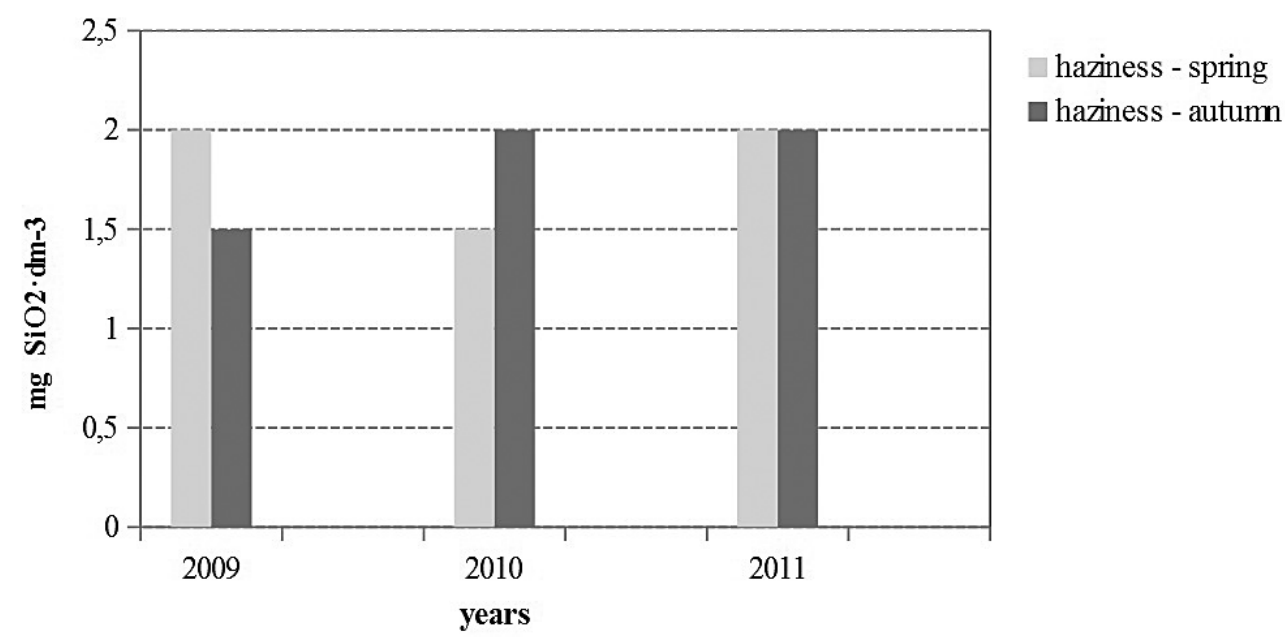

Figure 2. Seasonal changes in the haziness in the Łydynia river in 2009-2011

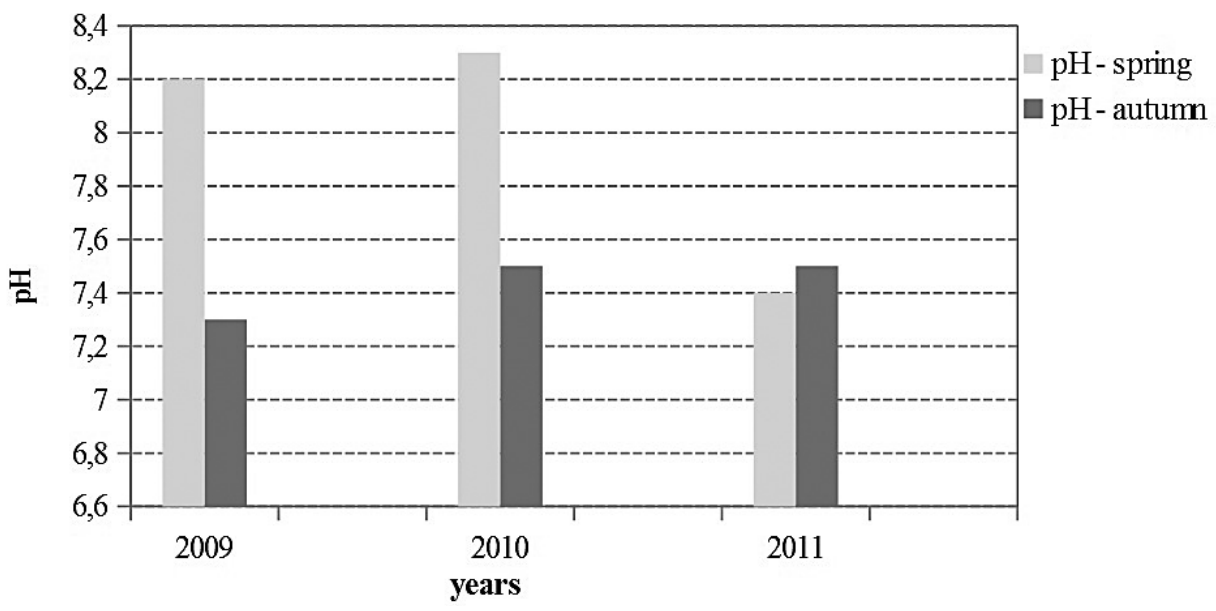

Figure 3. Seasonal changes in the $\mathrm{pH}$ in the Eydynia river in 2009-2011

conductance was recorded in the spring of 2010 $\left(145.9 \mu \mathrm{S} \cdot \mathrm{cm}^{-1}\right)$ and the lowest in the autumn of $2011\left(58.1 \mu \mathrm{S} \cdot \mathrm{cm}^{-1}\right)$. Contrasting results were reported by Augustyn et al. [2012] who demonstrated a tendency for the indicator to increase in the period from spring to winter. Augustyn et al. [2012], Chomutowska and Wilamowski [2014], Płytka et al. [2013] demonstrated that specific conductance for the following rivers: Łutownia, Wisłoka and Bochotniczanka fell within the following respective ranges: $338-434$ $\mu \mathrm{S} \cdot \mathrm{cm}^{-1}, 397.8-599.0 \mu \mathrm{S} \cdot \mathrm{cm}^{-1}$, and around 750 $\mu \mathrm{S} \cdot \mathrm{cm}^{-1}$. Wysocka-Czubaszek [2014] found the values of the indicator to range from 459 to 838 $\mu \mathrm{S} \cdot \mathrm{cm}^{-1}$ throughout the whole study period (the Biała river). The values for specific conductance obtained in the study reported here were lower compared with other Polish rivers and demonstrated that the Łydynia river has got class I water [Regulation of the Minister of Environment of 9 November 2011].
Figure 5 shows changes in calcium ion content in 2009-2011. In the spring, the calcium ion concentration in the water studied was between 100.6 and $102.2 \mathrm{mg} \cdot \mathrm{dm}^{-3}$ whereas in the autumn the range was 95 to $95,9 \mathrm{mg} \mathrm{Ca}^{2+} \cdot \mathrm{dm}^{-3}$. Average values of calcium ion content in the study periods were typical of class I water (Figure 5). Wysocka-Czubaszek [2014] obtained the range from 46.8 to $68.6 \mathrm{mg} \mathrm{Ca}^{2+} \cdot \mathrm{dm}^{-3}$ for water in the upper part of the Biała river whereas in the lower part, the values ranged from 85.8 to $216 \mathrm{mg} \mathrm{Ca}^{2+} \cdot \mathrm{dm}^{-3}$. The concentration of magnesium ions in the water of the Lydynia river was higher in the autumn, the highest being in $2010\left(27.9 \mathrm{mg} \mathrm{Mg}^{2+} \cdot \mathrm{dm}^{-3}\right)$ and the lowest in $2009\left(19.2 \mathrm{mg} \mathrm{Mg}^{2+} \cdot \mathrm{dm}^{-3}\right)$. The values recorded in autumn ranged from 16.2 to $21.9 \mathrm{mg} \cdot \mathrm{dm}^{-3}$ (Figure 6). The indicator of pollution did not exceed the limit value for class I water. WysockaCzubaszek [2014] reported the values for the Biała river ranging from 11.5 to $13.2 \mathrm{mg} \cdot \mathrm{dm}^{-3}$. 


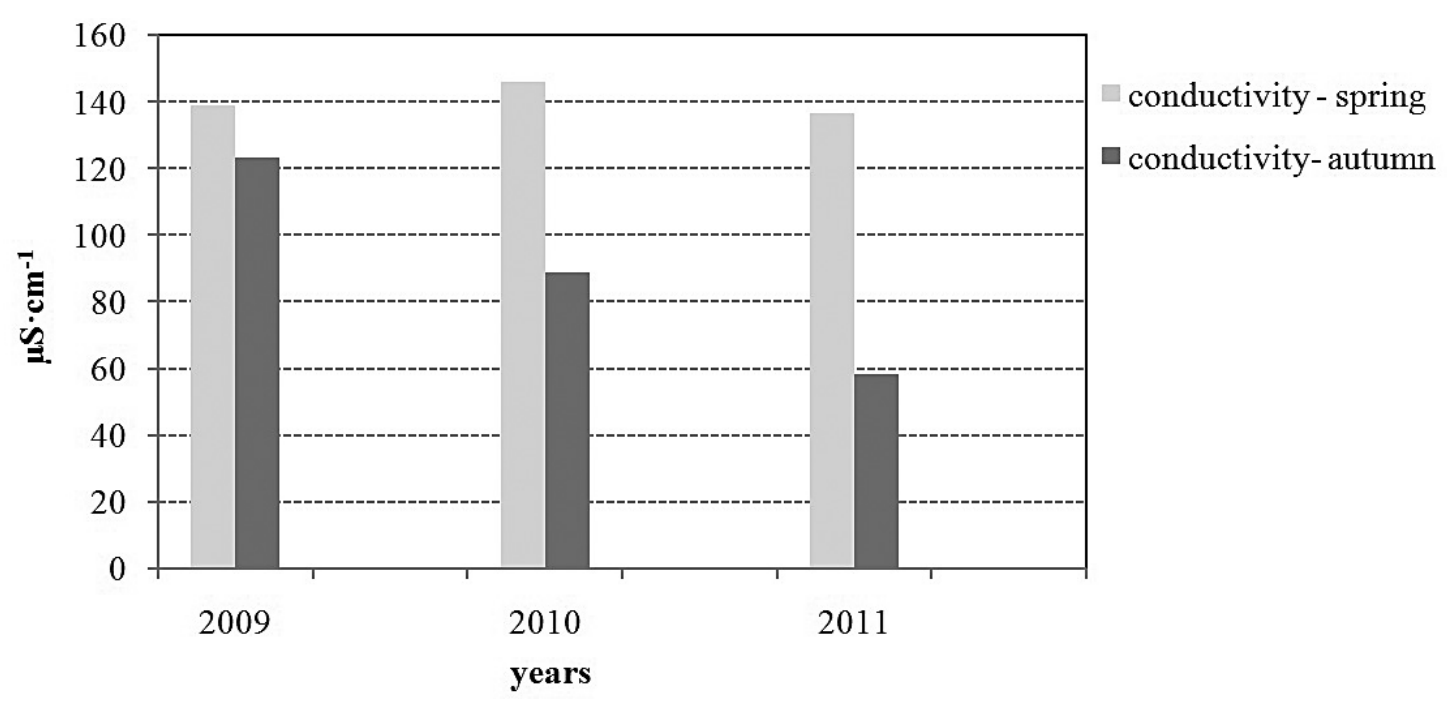

Figure 4. Seasonal changes in the conductivity in the Lydynia river in 2009-2011

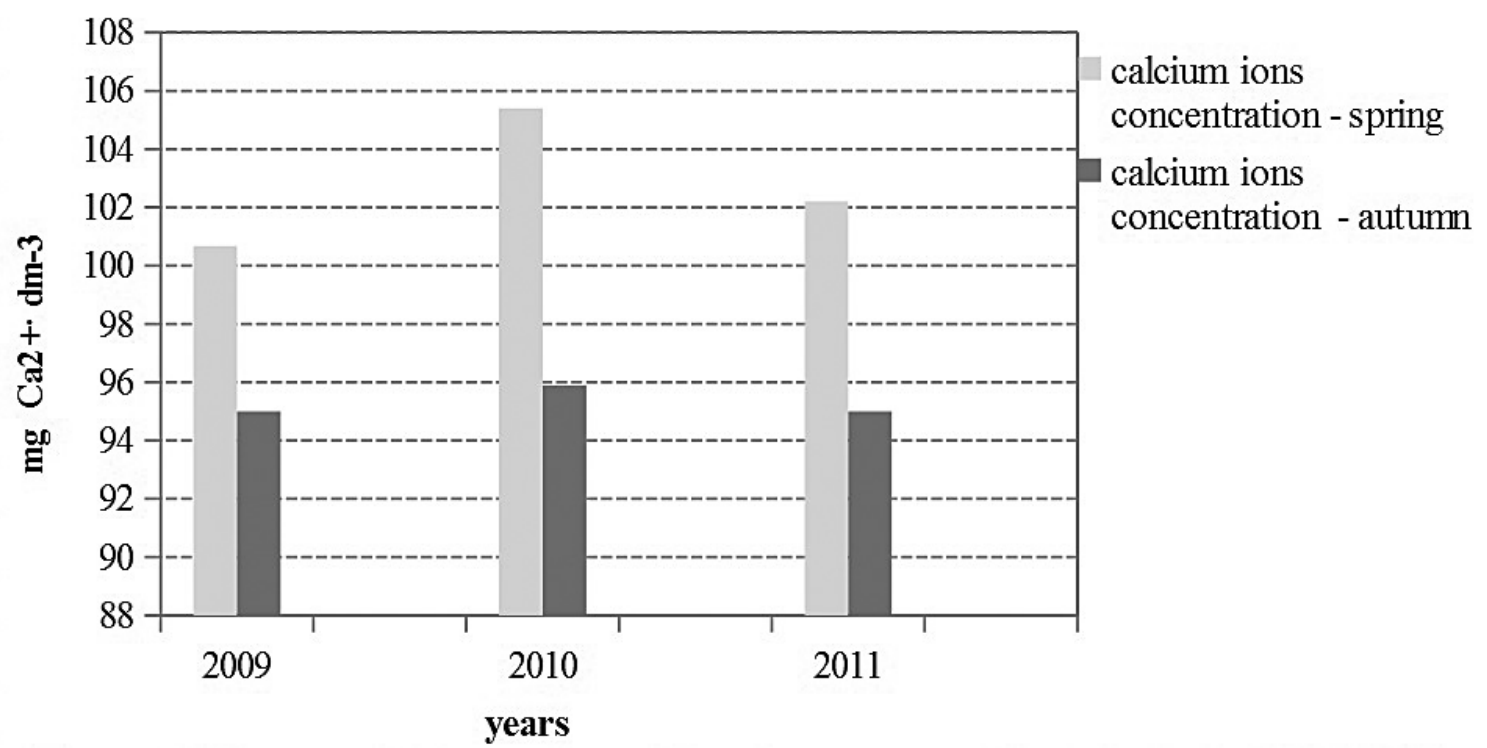

Figure 5. Seasonal changes in the content of calcium ions in the Łydynia river in 2009-2011

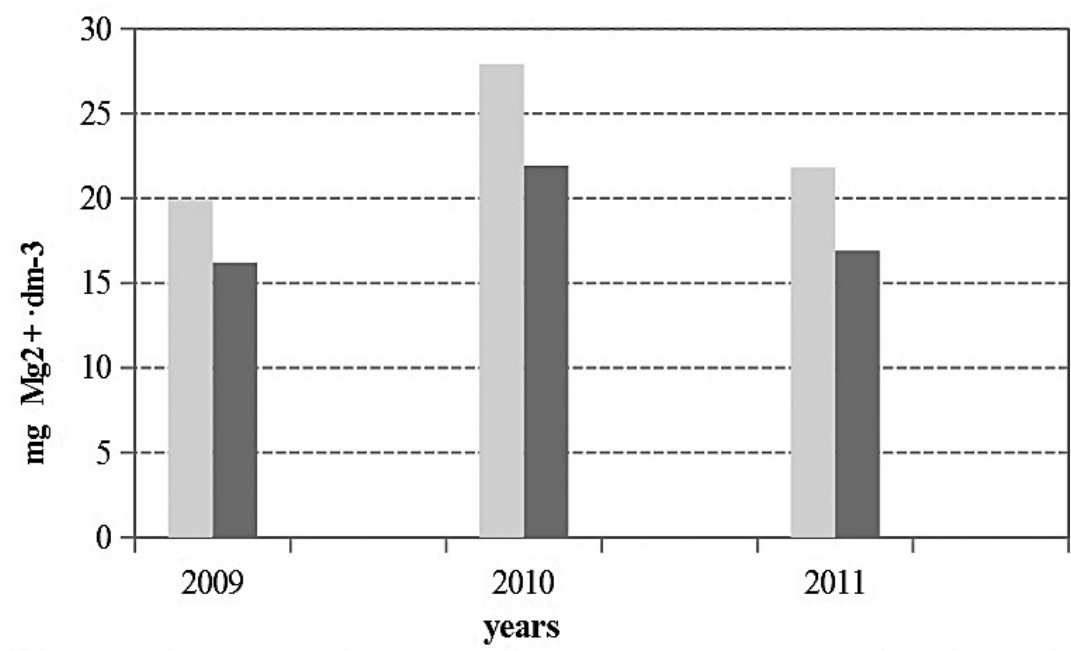
magnesiumions concentration - spring
- magnesiumions concentration- autumn

Figure 6. Seasonal changes in the content of magnesium ions in the Łydynia river in 2009-2011 


\section{CONCLUSIONS}

1. Physical and chemicals indicators which demonstrated that the water of the Lydynia river was of very good quality were: $\mathrm{pH}$, concentration of calcium and magnesium ions, and specific conductance. Their values did not exceed the limit values of class I waters set for waterbody of natural surface waters such as rivers.

2. The study results varied and depended on seasons of the year and study years.

3. Higher values of pollution indicators were recorded in autumn.

\section{REFERENCES}

1. Augustyn Ł., Kaniuczak J., Stanek-Tarkowska J. 2012. Wybrane właściwości fizykochemiczne i chemiczne wód powierzchniowych Wisłoki przeznaczonych do spożycia. Inżynieria Ekologiczna, 28, 8-19.

2. Bonisławska M., Szmukała M., Szaniawska D. 2008. Sezonowe zmiany jakości wód ujściowego odcinka rzeki Wiśniówki. Przemysł chemiczny, 87/5, 416-418.

3. Borowski G. (red.) 2010. Leksykon ekoinżynierii. Polskie Towarzystwo Inżynierii Ekologicznej, Warszawa.

4. Chomutowska H., Wilamowski K. 2014. Analiza czystości wód rzeki Łutownia na terenie Puszczy Białowieskiej. Inżynieria Ekologiczna, 38, 117-128.

5. Directive 2000/60/EC of the European Parliament and of the Council of 23 Oct. 2000 estabilishing a framework for Community action in the field of water policy. OJEC L 327/1 of 22.12.2000

6. Dojlido J.R. 1995. Chemia wód powierzchniowych. Wyd. Ekonomia i Środowisko, Białystok.

7. Hermanowicz W., Dojlido W., Dożańska W., Koziorowski B., Zerbe J. 1996. Fizykochemiczne badanie wody i ścieków. Arkady. Warszawa.

8. Natkaniec J., Możdżeń M. 2013. Zmiany stężeń wskaźników jakości wód rzeki Drwinki. Acta Sci. Pol., Formatio Circumiectus, 12 (2), 51-60.

9. Olszewska B., Krzemińska A. 2007. Jakość wód rzeki Jeziorki w latach 1995-2003. Inżynieria Ekologiczna, 18, 190-192.

10. Ostrowski K., Policht A., Rajda W., Bogdał A. 2007. Zmiany przewodności elektrolitycznej i stężeń biogenów w wodzie z biegiem cieku odwadniającego małą zlewnię rolniczą. Inżynieria Ekologiczna, 18, 195-196.

11. Pytka A., Jóźwiakowski K., Marzec M., Gizińska M., Sosnowska B. 2013. Ocena wpływu zanieczyszczeń antropogenicznych na jakość wód rzeki Bochotniczanki. Infrastruktura i Ekologia Terenów Wiejskich, 3/II, 15-29.

12. Rozporządzenie Ministra Środowiska z dnia 9 listopada 2011 r. w sprawie klasyfikacji stanu jednolitych części wód powierzchniowych oraz środowiskowych norm jakości dla substancji priorytetowych (Dz.U. z 2011 r. Nr 257 poz. 1545).

13. Wysocka-Czubaszek A. 2014. Sezonowa zmienność chemizmu wody w małej rzece w zlewni zurbanizowanej. Prz. Nauk. Inż. Kszt. Środ., 63, 64-76.

14. http://www.gios.gov.pl/pl/stan-srodowiska/monitoring-wod 